ent responses dependent on factors such as soil-base saturation levels, sulphate adsorption and release mechanisms, weathering rates, hydrological factors and deposition rates. Although there are many uncertainties in the MAGIC model $^{7}$, the diatom records suggest that the model is applicable under these circumstances. Indeed, the model provides the only means of making site-specific or regional predictions of long-term future behaviour of stream and lake acidity.

On this basis, the observed improvements in Scotland, which are also suggested by the MAGIC model, should not be viewed as a case against further controls of acidic oxide emissions. Indeed, the modelling evidence suggests that further large-scale reductions are required and the amelioratory effects will be relatively rapid. Preliminary estimates for the United Kingdom, using the MAGIC model, indicate deposition reductions of around 50 per cent from 1985 levels are required to obtain significant long-term recovery ${ }^{+*}$ for much of the British uplands.

Colin Neal.

Paul Whitehead Al_AN JENKINS

Institute of Hydrology,

Crowmarsh Gifford,

Wallingford $O X 108 B B, U K$

1. Battarbee, R.W. et al. Nature 332, 530-532 (1988)

2. Cosby, B.J., Wright, R.F. Hornberger, G.M. \& Galloway J.N. Water Resour. Res. 21. 1591-1601 (1985)

3. Whitehead, P.G.\& Neal, C. Trans. R. Soc. Edin. Earth Sci. 78, 385-392 (1987)

4. Neal, C., Whitehead. P.G., Neale, R. \& Cosby, B.J. J. Hydrol. 86, 15-26(1986).

5. Cosby, B.J.. Whitehead, P.G. \& Neale, R. J. Hydrol. 84. 381-401 (1986).

6. Cosby, B.J. Proc. Reversibility of Acidification Workshop EEC DGX11/G-1, 137-148 (1986)

7. Neal, C. \& Whitehead, P.G. Hydrol. Sci. Bull. 33, 103 (1988)

8. Whitehead. P.G.et al.J. Hydrol. (in the press)

9. Flower, R.J. \& Battarbee, R.W. Nature 305, 130 (1983).

\section{Punctuation and selection}

SIR-Radical theoretical positions in science are like programme trading in the securities markets: during euphoric uptrends their authors are not averse to taking full credit; but in the downward spiral that inevitably follows when reason returns, those associated with the movement no longer wish to be acknowledged.

This parallel came to mind as I read Steven Stanley's charge' that John Maynard Smith, in his criticism ${ }^{2}$ of Eldredge and Gould's punctuational model of evolution, has seriously misrepresented Stanley's writings on species selection. Actually, Maynard Smith mentioned Stanley only twice. The second mentioned deals with a dispute over whether the evidence for punctuation has been in the form of measured morphological change or, instead, the duration of named taxa in the fossil record. Stanley does not mention this in his reply, so we can assume that his discomfort focuses on the other point: the decoupling of macro- evolution from microevolution, and the role of random elements therein.

Specifically, Maynard Smith is charged with having "quoted out of context" a statement of Stanley's that refers to a "strong random element" in speciation. I have checked the passage in question (p.187 of ref. 3) and find my reading to be the same as Maynard Smith's. Indeed, shortly afterwards (p.193 of ref. 3) Stanley makes the case that species selection should not be considered as a subdivision of natural selection, and he asserts (p. 212) that "transitions are opportunistic in nature, reflecting the 'experimental' nature of speciation".

In the matter of quotes out of context, however, readers should consider Stanley's own statement that "although he never considered the process in detail, Wright asserted that selection operates at the level of the species..." Wright's paper $^{+}$thus referenced is his classic Modes of Selection, in which the concluding sentence takes the rather more eclectic stance that "The course of evolution of vertebrate life and of life in general has been guided throughout by a hierarchy of processes of selection ranging from selection between genes to selection between orders, classes and even phyla." Significantly, the same paper opens with what Wright called the dogmatic statement of his general position with regard to evolution: "Adaptation rather than mere change seems to me to be the central problem. The only mechanism for evolutionary adaptation that has held up under investigation is natural selection." In Stanley's main publication on patterns of evolution $^{3}$, the concept of adaptation is conspicuous by its virtual absence.

ROBERT B. ECKHARdT The Pennsylvania State University,

\section{University Park,}

Pennsylvania 16802, USA

Stanley, S.M. Nature 333, 214 (1988).

Maynard Smith, J. Nature 330, 516 (1987); 332, 311 (1988). Stanley, S.M. Macroevolution (Freeman, San Francisco. 1979).

Wright, S. Am. Nat. 90, 5 (1956).

\section{Understanding aggression}

SIR-Had Melvin Konner been willing to take our book (Aggression: Conflict in Animals and Humans Reconsidered) a little more seriously, he might have understood it rather better'. We are not, as he suggests, anti-sociobiological; on the contrary, we endorse the sociobiological enterprise and attempt to reassess the significance of evolutionary theory for an understanding of aggression.

In this process of reassessment we do indeed criticize the work of several sociobiologists, including Konner himself (though not, as he suggests, either Robert Axelrod or Richard Dawkins). Our quarrel with Konner has to do with his use of selected ethnographic material to support the view that "no cultural training, however designed, can eliminate the basic core of capability of violence that is part of the makeup of human beings"'. Since our book was sent to press, the authors of the relevant ethnographic material have themselves complained about this misuse of their work ${ }^{3}$.

The proper response to criticism is counter-criticism. Konner ignores this and all other substantive issues, contenting himself instead with a rhetorical plea: "Respected critics of sociobiology! Surely you can do better than this!". The answer is obvious: "Respected sociobiologists! Surely you can do better than Konner!".

Department for External Studies,

John R. Durant

University of $O x$ ford

Oxford $O X I 2 J A, U K$

Konner. M. Nature 333, 405 (1988)

Konner, M. The Tangled Wing. 207 (Heinemann, London. 1982).

Robarchek. C.A. \& Dentan. R.K. Am. Anthropol. 89(2), $356-365(1987)$.

\section{Segregation of cystic fibrosis allele}

SIR-Kitzis et al. (Nature 333, 215; 1988) suggest that the high frequency of the cystic fibrosis (CF) mutant gene in Caucasian populations may have arisen from the preferential inheritance of the $\mathrm{CF}$ chromosome from male to male. This intriguing hypothesis was based on the haplotyping of 60 asymptomatic siblings of CF patients by DNA probes. Twenty of 22 normal homozygotes were girls, 16 of 21 paternal $\mathrm{CF}$ chromosomes were inherited by boys. This is at odds with our own haplotyping of 60 unaffected siblings from 41 German CF families. Ten girls and 10 boys were typed homozygous normal. Eight of 17 paternal $\mathrm{CF}$ chromosomes and 15 of $23(65 \%)$ maternal CF chromosomes had been passed to boys.

If one compiles the data from the two studies, the proportion of maternal and paternal CF alleles is about 1 to 1 in both male and female CF carriers, as expected for autosomal mendelian inheritance. Hence, an unfortunate sampling bias may be the most likely explanation for the unexpected segregation of the CF allele to the male germline observed by Kitzis et al. The data still do not exclude the possibility of a slightly more frequent transmission of CF chromosomes to males. More extensive data from pedigree analyses and population studies on unrelated individuals should settle the issue.

B. TÜMMLER

A. Aschendorf

T. DARNedDe

J. HuNDRIESER

Zentren Biochemie und Humangenetik,

Medizinische Hochschule Hannover.

D-3000 Hannover 61, FRG 